\title{
Temporal Analysis for Multi-hazard Risk Assessment of Rice Cultivation in Coastal Areas: A Case Study of Soc Trang, Vietnam
}

\section{Thanh Quoc Vo}

IHE Delft Institute for Water Education https://orcid.org/0000-0001-5940-1798

Trung Hieu Nguyen ( $\nabla$ nhtrung@ctu.edu.vn )

Research Institute for Climate Change, Can Tho University, Vietnam

Vo Thi Phuong Linh

Can Tho University

\section{Research}

Keywords: risk assessment, tropical cyclones, salinity, Mekong Delta, rice cultivation

Posted Date: January 6th, 2021

DOI: https://doi.org/10.21203/rs.3.rs-137318/v1

License: (c) (i) This work is licensed under a Creative Commons Attribution 4.0 International License.

Read Full License 


\section{Temporal analysis for multi-hazard risk assessment of rice cultivation in}

2 coastal areas: a case study of Soc Trang, Vietnam

3 Vo Quoc Thanh ${ }^{1}$, Nguyen Hieu Trung ${ }^{2 *}$, Vo Thi Phuong Linh ${ }^{1}$

$4 \quad{ }^{1}$ College of Environment and Natural Resources, Can Tho University, Vietnam

$5 \quad{ }^{2}$ Research Institute for Climate Change, Can Tho University, Vietnam

$6 \quad$ Correspondence: nhtrung@ctu.edu.vn

8 Abstract

Rice is an important human crop and rice cultivation is threatened due to natural disasters, leading to negative effects on national and global food security. The natural disasters, such as tropical cyclones and saline intrusion, have dramatic influences in coastal regions. To investigate possible impacts of these disasters on rice cultivation, it needs an efficient tool to assess potential disasters impacts and a risk index is highly applicable. Therefore, this study aims at establishing a risk assessment of rice production in coastal areas under effects of tropical cyclones and saline intrusion. We adopted risk definition introduced by IPCC (2014) in which risk is a function of hazard, exposure and vulnerability. Multiple hazards of tropical cyclones and saline intrusion were indicated by their frequency and severity at some critical levels of $25 \%, 50 \%$ and $>50 \%$ rice yield reduction. Each hazard was weighted by its damage on rice yield. Exposure and vulnerability of rice crops are evaluated at different growing phases. Tropical cyclone hazard index was ranked high and very high in the wet season while salinity hazard index was ranked very high in the dry season. Due to the combined effects of tropical cyclones and salinity, rice crop is highly susceptible during the reproduction phase and at the panicle initiation stage particularly. Based on the cropping calendar of My Xuyen, the period of October-November was the very high vulnerability period since it had the largest rice cultivable area and rice crops were at the reproduction phase. This result shows that rice crops are at high risk in October and November. Noticeably, saline intrusion reaches the highest level in April and May, but no risk is at this period because of no rice crop cultivated. This can reflect a measure to reduce risk by adjusting the cropping calendar. 
Keywords: risk assessment, tropical cyclones, salinity, Mekong Delta, rice cultivation.

\section{1. Introduction}

32 According to FAO (2017) natural disasters caused damages of agricultural productions,

33 including crops and livestock, about USD 93 billion in developing countries in a decade (2005-

34 2014). Among these natural disasters, tropical cyclones are one of the main disastrous

35 phenomena causing considerable damages around the world which cause a damage of USD 26

36 billion annually (Mendelsohn et al. 2012). In addition, there is an annual loss of approximately

37 USD 12 billion due to saline-affected land (Qadir et al. 2008). The mentioned damaged

38 phenomena are the major factors affecting coastal areas.

39 The Vietnamese Mekong Delta (VMD) is located at the downstream of the Mekong River which

40 is one of the largest rivers in the world (MRC 2010). The VMD is a crucial economic region in

41 Vietnam. Moreover, it plays an important role in ensuring food security not only for Vietnam,

42 but also for the world since the VMD contributes up to $90 \%$ to the annual rice export of Vietnam

43 (GSOVN 2010). With the land resources of approximately 4 million ha, three-quarters of this

44 area is used for agricultural production (Kakonen 2008). Therefore, rice production in the coastal

45 VMD is facing challenges of tropical cyclones and saline intrusion. For example, Soc Trang is a

46 coastal province, dealing with these challenges. Although Soc Trang is a coastal province, rice is

47 the major agricultural products. Consequences, rice cultivation in Soc Trang is at risk of tropical

48 cyclones and saline intrusion effects. Generally, to reduce risk of these events, it needs to

49 conduct a risk assessment to evaluate how rice crops can be damaged. Risk is resulted from

50 interaction of hazard and vulnerability (Merz et al. 2010). In order to assess risk, it requires

51 hazard and vulnerability assessment. The outputs of these assessment support decision making 
process.

53 There are some methods to assess hazard and vulnerability using indicators, field or lab

54 experiments and numerical models (Buan et al. 1996; Zeng and Shannon 2000; Zeng et al. 2001;

55 Hakim et al. 2010; Bauder et al. 2011; Kunitsugu 2012; Lee et al. 2012; Masutomi et al. 2012;

56 Tri et al. 2013; Bates et al. 2014; Esteban et al. 2014; IRRI 2015; Kakar et al. 2019). In

57 comparison, using indicators is a rapid and simple method compared to the others mentioned.

58 For instance, Balica et al. (2012) developed a coastal city flood vulnerability index which is able

59 to assess vulnerability to flood and evaluate adaptation options. Tri, Trung, and Thanh (2013)

60 applied this index to evaluate impacts of the projected climate change and sea level rise on flood

61 vulnerability in the VMD. It is determined that vulnerability index is an effective and rapid tool

62 to assist managers and decision-makers in assessing impacts of predicted scenarios and

63 improving decision-making procedure. The outputs resulted in applying this index enhance

64 mitigation and adaptation strategies. Therefore, this study is conducted to establish a risk

65 assessment of rice production due to effects of tropical cyclones and saline intrusion. We

66 assessed impacts of tropical cyclones and saline intrusion on rice production in a coastal area

67 (My Xuyen district, Soc Trang province, Vietnam, presented in Figure 1) by using the risk

68 definition of IPCC (2014). Based on this definition, risk includes hazard, exposure and

69 vulnerability components. Rice is an important food crop and is grown seasonally, so rive crops

70 are not always available on the field. This suggests that a temporal analysis should be taken into

71 account for the risk assessment. The outputs of the risk assessment helps to mitigate and reduce

72 impacts of tropical cyclones and saline intrusion on rice cultivation. 


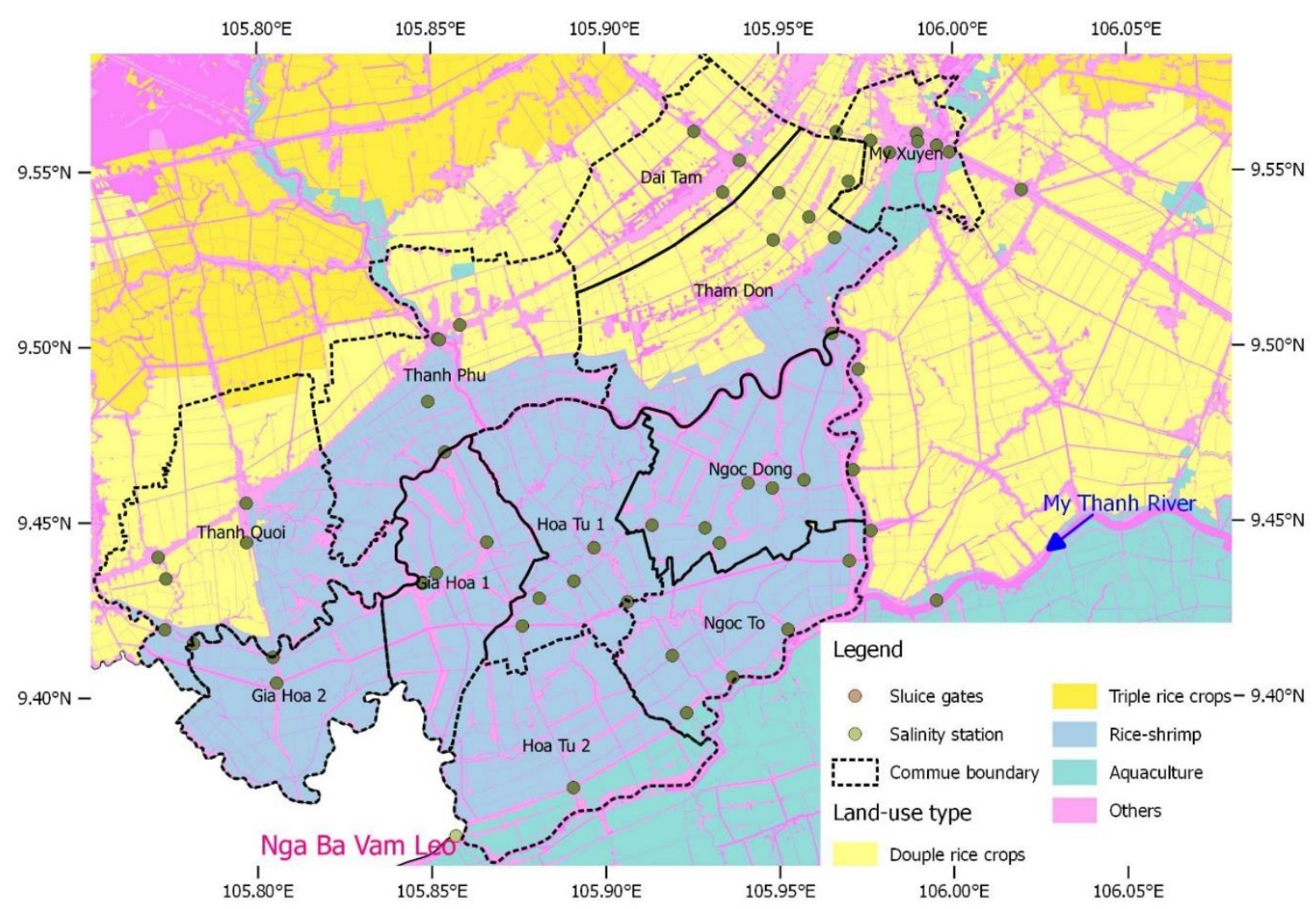

74 Figure 1. Land-use map in 2010 of My Xuyen district.

\section{2. Methods}

\subsection{Risk definition}

77 To identify the natural hazard risk, we used the definition of IPCC (2014) in which risk is

78 defined as a function of hazards and consequences which present the impacts of the hazardous

79 events. In a hazardous event, its impacts are highly depended on vulnerability and exposure.

80 Therefore, risk is defined by the three components of hazard, exposure and vulnerability.

$$
\text { risk }=\mathrm{f}(\text { hazard, } \text { exposure, } \text { vulnerability) }(1)
$$

82 Hazard describes probability of occurrence and intensity of natural or human-induced events

83 such as storms, floods and saline intrusion. Exposure shows the presence of people, 
84 infrastructure, livelihoods, environmental functions, services, etc. in the region that could be

85 affected by the events. Vulnerability is identified as the extent of harm, including

86 sensitivity/susceptibility and resilience. There is a broad set of elements of an system which is

87 suffering from the natural disasters. This set can be characterized by hydrogeological, social and 88 economic components (Tri et al. 2013; Balica et al. 2014).

\subsection{Multiple natural hazard assessment}

90 In order to assess natural hazards, the main hazardous events which cause considerable damages

91 on agricultural production are selected for the assessment. Identifying and assessing hazardous

92 events help to understand their nature and behaviour, suggesting awareness and planning for

93 disaster mitigation strategies. The natural hazards was assessed in terms of frequency, affected

94 areas and degree of severity. In reality, a number of natural events threaten the agricultural

95 production in the coastal area, such as saline intrusion, tropical cyclones, tornadoes, etc. These

96 threats were selected for multi-hazards assessment based on their damages on agricultural crops

97 in the study area and this was observed by the Department of Agriculture and Rural

98 Development of My Xuyen district. We assessed the impacts of multi-hazards on agricultural

99 crops, focusing on rice crops. The agricultural crops are only influenced by the natural hazards

100 during their cultivated durations which are represented by their cropping calendars. The major

101 land-use types in My Xuyen district are agriculture and aquaculture, consisting of intensive rice

102 farming, intensive shrimp farming and rice-shrimp farming (Thảo et al. 2017). Therefore, a

103 temporal analysis is important for the hazard assessment and its temporal resolution should be

104 fine enough to present seasonal variations of the cropping systems. In this study, the monthly

105 interval are reasonable for presenting the cropping calendar of each farming system. 

where $H I$ is multiple hazard index; $H I_{i}$ is the hazard index of phenomenon $i ; w_{i}$ is the weight of

113 phenomenon $i$. The $H I_{i}$ of each phenomenon is computed based on its frequency and intensity.

114 The hazard index of each phenomenon should be normalized due to different range of the hazard

115 index. We used the weights in calculation of hazard index because this help to prioritize the 116 importance of each phenomenon. The weight of a phenomenon is simply identified as damage 117 percentage caused by that phenomenon of the total damage.

\section{Tropical cyclones}

119 Tropical cyclones are of the most destructive natural hazards not only in Vietnam but also over

120 the world. They affect large areas depending on their intensity and track of the tropical cyclones.

121 Wang et al. (2020) defined the warning area due to the tropical cyclones within an $800 \mathrm{~km}$

122 radius. Therefore, we analysed the tropical cyclones occurred within a circle whose radius is 800

$123 \mathrm{~km}$ from My Xuyen district. The tropical cyclones mentioned in this study are tropical storms or 124 greater events (e.g. severe tropical storms, typhoons, or hurricanes). Data of tropical cyclones,

125 which were recorded for the period of 1951 to 2019 by the Japan Meteorological Agency, were

126 used for the hazard assessment. The data contain characteristic features of tropical cyclone tracks

127 for every six hours. First, the eye's locations of tropical cyclones within the $800 \mathrm{~km}$ circle were 
128 selected. To assess tropical cyclone impact, we used and modified the Tropical Cyclone Potential 129 Index (TCI) which was introduced by (Xiao et al. 2011). Then monthly TCI was computed as 130 follows:

$$
T C I=\sum_{i=1}^{n} w_{i} v_{i}^{2}(3)
$$

$$
w_{i}=1-\frac{d_{i}}{800}(4)
$$

133 where $n$ is the number of points of 6-hour tropical cyclones in the circle; $v_{i}$ is the maximum

134 wind speed near the tropical cyclone center $i ; w_{i}$ is the weight of the tropical cyclone center $i$

135 which was calculated by its inverse distance to the study area; and $d_{i}$ is the distance between the 136 tropical cyclone center and the study area centroid $(\mathrm{km})$.

\section{Saline intrusion}

138 Saline intrusion is the most influential factor that impacts agricultural production in My Xuyen

139 district. Saltwater intrudes into My Xuyen district through the My Thanh River which are

140 directly connected to the East Sea (Bé et al. 2017). Salinity data from 2016 to 2019 at Nga Ba

141 Vam Leo (located in Hoa Tu 2, 


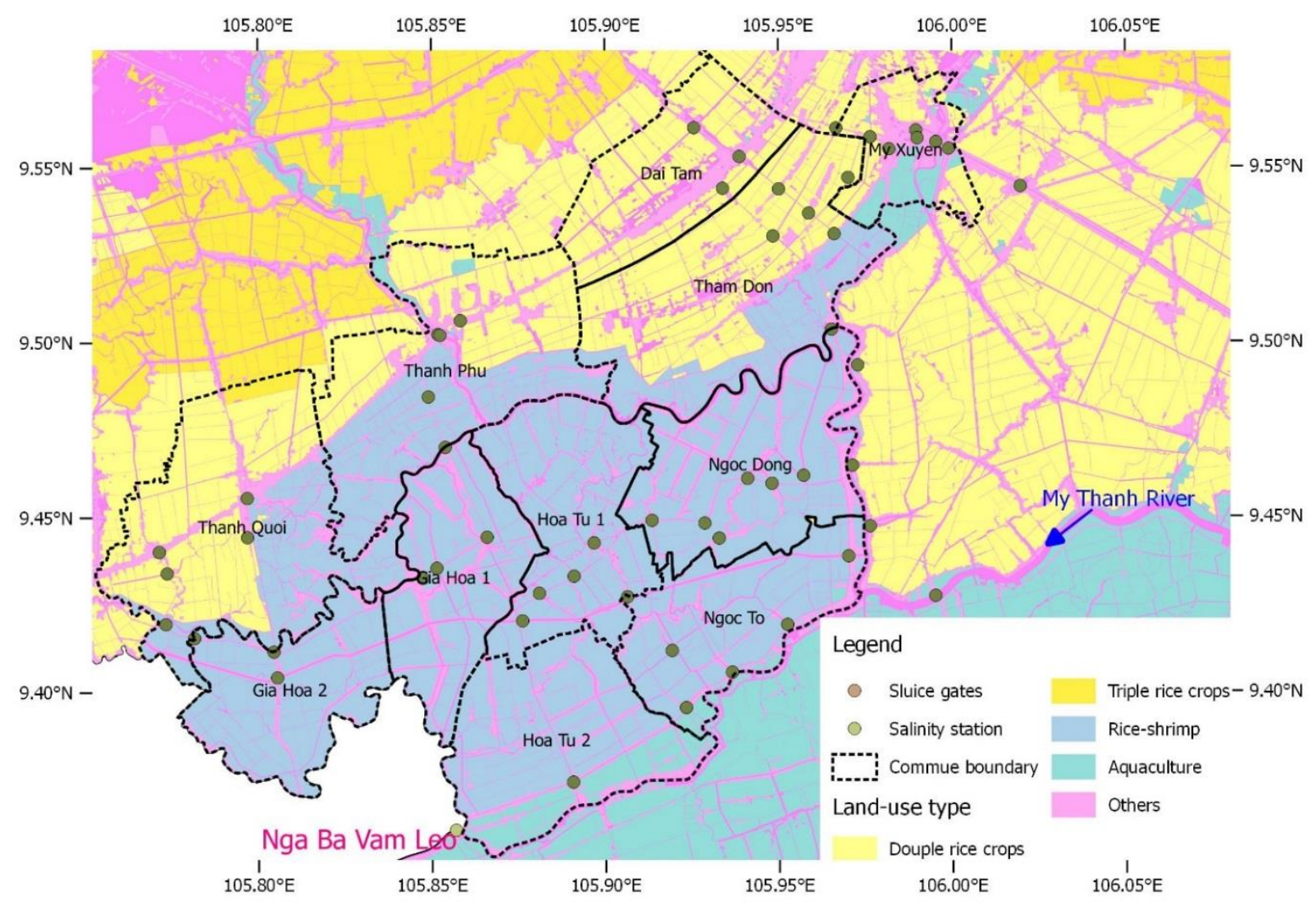

143 was collected by the Irrigation Management Station of My Xuyen district. These data of salinity

144 were analysed monthly frequency of salt stress. The levels of salt stress are identified based on

145 the cultivated crops and their stages. Generally, salinity levels of higher than $2 \mathrm{dS} / \mathrm{m}$ can reduce

146 rice yield regarding to timing of salt stress and rice variety (Asch and Wopereis 2001).

147 According to Ayers and Westcot (1985), the agricultural crops are not affected by the electrical

148 conductivity (EC) of irrigation water which is lower than $0.7 \mathrm{dS} / \mathrm{m}$. When the EC is higher than

$1490.7 \mathrm{dS} / \mathrm{m}$, the agricultural crops begin to be damaged slightly. The crops are severely affected by

150 the EC of higher than $3.0 \mathrm{dS} / \mathrm{m}$. This is a common classification for salt stress of irrigation water

151 for agriculture and this highly agrees with salinity hazard of irrigation water defined by Bauder

152 et al. (2011); Follett and Soltanpour (1914). Specifically, each agricultural crop has different

153 capacity to adapt to saline water. For instance, effects of saline water on rice yield were 
154 evaluated by Ayers and Westcot (1985) and is presented in Error! Reference source not

155 found.. Total dissolved solids (TDS) are the common data of water salinity and they were

156 estimated by using its relationship with EC. The average ratio of total dissolved solids and EC is

1570.64 (Ali et al. 2012).

158 Table 1. Salinity hazard categories of irrigation water for rice crops (Ayers and Westcot 1985).

\begin{tabular}{|l|l|l|l|}
\hline EC $(\mathbf{d S} / \mathbf{m})$ & TDS $(\mathbf{g} / \mathbf{l})$ & Category & Effects on rice crops \\
\hline $\mathrm{EC}<2.0$ & TDS $<1.3$ & None & Rare effect on rice yield \\
\hline $2.0 \leq \mathrm{EC}<3.4$ & $1.3 \leq \mathrm{TDS}<2.2$ & Slight & Reduction of 25\% rice yield \\
\hline $3.4 \leq \mathrm{EC} \leq 4.8$ & $2.2 \leq \mathrm{TDS} \leq 3.1$ & Moderate & Reduction of 50\% rice yield \\
\hline EC $>4.8$ & TDS $>3.1$ & Severe & Reduction of over 50\% rice \\
& & yield or destruction of rice crops \\
\hline
\end{tabular}

159 The salinity data collected were used to analyse the monthly frequency of the selected salinity

160 levels. To assess effects of saline water on rice crops, we defined the Salinity Potential Index

161 (SPI) based on salinity levels and their frequency, presented as follows.

$$
S P I=\sum_{i=1}^{3} n_{i} w_{i}(5)
$$

163 where $i$ is the number of salinity hazard categories, $n_{i}$ is the number of salinity occurrence of

164 the category $i, w_{i}$ is the category weights which are equal to $0.25,0.5$, and 1 for slight, moderate

165 and severe categories respectively. 


\subsection{Susceptibility of rice crops in the rice-based cropping system}

167 Rice is the major agricultural crops in My Xuyen district and the rice-based farming systems are

168 double rice crops and shrimp-rice crops. Rice crops are highly susceptible to the effects of

169 tropical cyclones and salinity in irrigation water. Each type of these hazardous events has a

170 different way to influence the rice crops.

\section{Effects of tropical cyclones}

172 The tropical cyclones damage the rice crops due to high wind velocities which leads to injury of 173 plant organs. Masutomi et al. (2012) found that the highest rice vulnerability to tropical cyclones

174 is the heading stage and assumed that the fragility curve of rice plants can be formulated by the

175 Weibull distribution. Therefore, rice vulnerability to tropical cyclones was computed from the 176 damage ratios introduced by Masutomi et al. (2012).

\section{Effects of saline intrusion}

178 The rice crops are highly vulnerable to salt stress and the damages are corresponded to their

179 growth stages. The rice crops are really sensitive to salinity, particularly at the seedling stage

180 (Grattan et al. 2002; Kakar et al. 2019). By another way, saline irrigation water increases salt

181 accumulation in the crop root zone and this causes that the rice crops are not able to sufficient

182 water. Moreover, the saline irrigation water can slow growth rate of rice plants, leading to a

183 reduction or a loss of rice yield. Salinity in irrigation water differently influences rice growth and

184 yield during the growing stages. Thus we used the cropping calendar of the farming systems in

185 order to analyse susceptibility of the rice crops. During the seedling stage, effects of saline water 186 on rice growth at different timing during the vegetative stage are relatively similar. These effects 
187 in the reproductive phase are slightly higher in the vegetative phase (Zeng et al. 2001). In this

188 study, the susceptibility of rice was indicated by reduction of rice yields. The reduction of rice

189 yields at different timing of salinity was computed based on experimental data of Rad et al.

190 (2011). These reductions are considerably changed under different salinity levels, illustrated in

191 Table 2. Rice growth has similar patterns of responses to the different salinity levels during

192 growing phases (Figure 2). The panicle initiation is the most susceptible stage in which rice yield

193 can be reduced by a half due to effects of $4 \mathrm{dS} / \mathrm{m}$ salinity. We used average reduction of rice

194 yield due to 2 and $4 \mathrm{dS} / \mathrm{m}$ salinity for indicating rice sensitivity during growing phases. At the

195 seedling stage, rice survival is about $70.2 \%$ because of impacts of $3.3 \mathrm{dS} / \mathrm{m}$ salinity (Zeng et al.

196 2003). Response of the rice crops to salinity is highly various because of rice varieties. We

197 assumed that the rice varieties cultivated in My Xuyen district has similar capacity to response to 198 salinity and tropical cyclones to those in experiments of Masutomi et al. (2012) and Rad et al.

199 (2011).

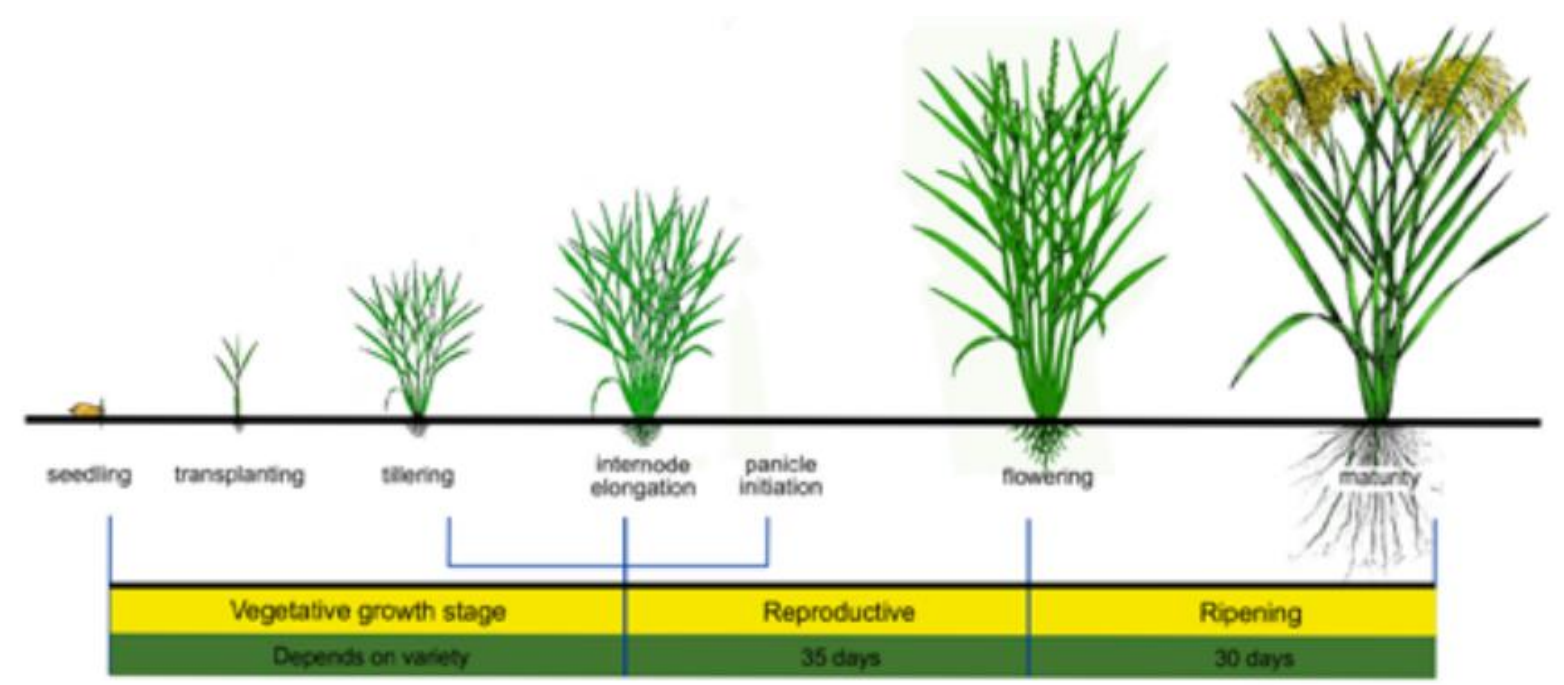

200

201 Figure 2. The growth stages of rice (IRRI 2015).

202 Table 2. Reduction of rice yield at different timing of salinity (Rad et al. 2011). 


\begin{tabular}{|l|l|l|l|l|}
\hline $\begin{array}{l}\text { EC } \\
(\mathbf{d S} / \mathbf{m})\end{array}$ & Tillering & $\begin{array}{l}\text { Panicle } \\
\text { initiation }\end{array}$ & Heading & Ripening \\
\hline 2 & $26 \%$ & $43 \%$ & $9 \%$ & $4 \%$ \\
\hline 4 & $33 \%$ & $50 \%$ & $13 \%$ & $3 \%$ \\
\hline Average & $30 \%$ & $46 \%$ & $11 \%$ & $4 \%$ \\
\hline
\end{tabular}

203 The decreased percentages of rice yields were normalized. Values of the vulnerability index were

204 normalized on a scale from 0 to 1 where vulnerability is lowest or highest respectively. These

205 vulnerability are grouped into five categories, presented in Table 3.

206 Table 3. Categories of vulnerability.

\begin{tabular}{|l|l|l|}
\hline Category & Hazard and vulnerability & Risk \\
\hline Very low & $0-0.2$ & $0-0.04$ \\
\hline Low & $0.2-0.4$ & $0.04-0.16$ \\
\hline Moderate & $0.4-0.6$ & $0.16-0.36$ \\
\hline High & $0.6-0.8$ & $0.36-0.64$ \\
\hline Very high & $0.8-1$ & $0.64-1$ \\
\hline
\end{tabular}

3. Results and discussion

208 Many regions are exposed to a number of natural hazards depending on their spatial 
209 characteristics. There are several specializing hazards in coastal areas such as tropical cyclones

210 and saline intrusion. It is evident that these natural hazards cause huge damage to agricultural

211 production in the coastal areas. Therefore, the outputs of the hazard and vulnerability assessment

212 assist to deal with risks of these phenomenon. In this section, we present results of hazard,

213 vulnerability and risk assessment of the mentioned hazardous events, influencing the rice crops

214 in My Xuyen district.

\section{3.1. Temporal hazard assessment}

216 Figure 3 shows the tropical cyclone tracks within the region of potential effects from 1951 to

217 2019. There are 136 tropical cyclones occurred in the region. The tropical cyclones originate

218 from the eastern-oriented directions, developing in the Pacific Ocean. Generally, the tropical

219 cyclones occur during the southwest monsoon season. The monthly numbers of tropical cyclones

220 are presented Figure 4. My Xuyen has high potential effects of tropical cyclones from September

221 to December, particularly in October and November which contribute to over a half of the total

222 tropical cyclone number. The tropical cyclones are rarely approach the southern coast (My

223 Xuyen district) while they hit the central and northern parts of Vietnam (Takagi et al. 2014). It is

224 obviously evident that the tropical cyclones move to the south from November to February. This

225 is indicated by the low latitudes of tropical cyclones. 


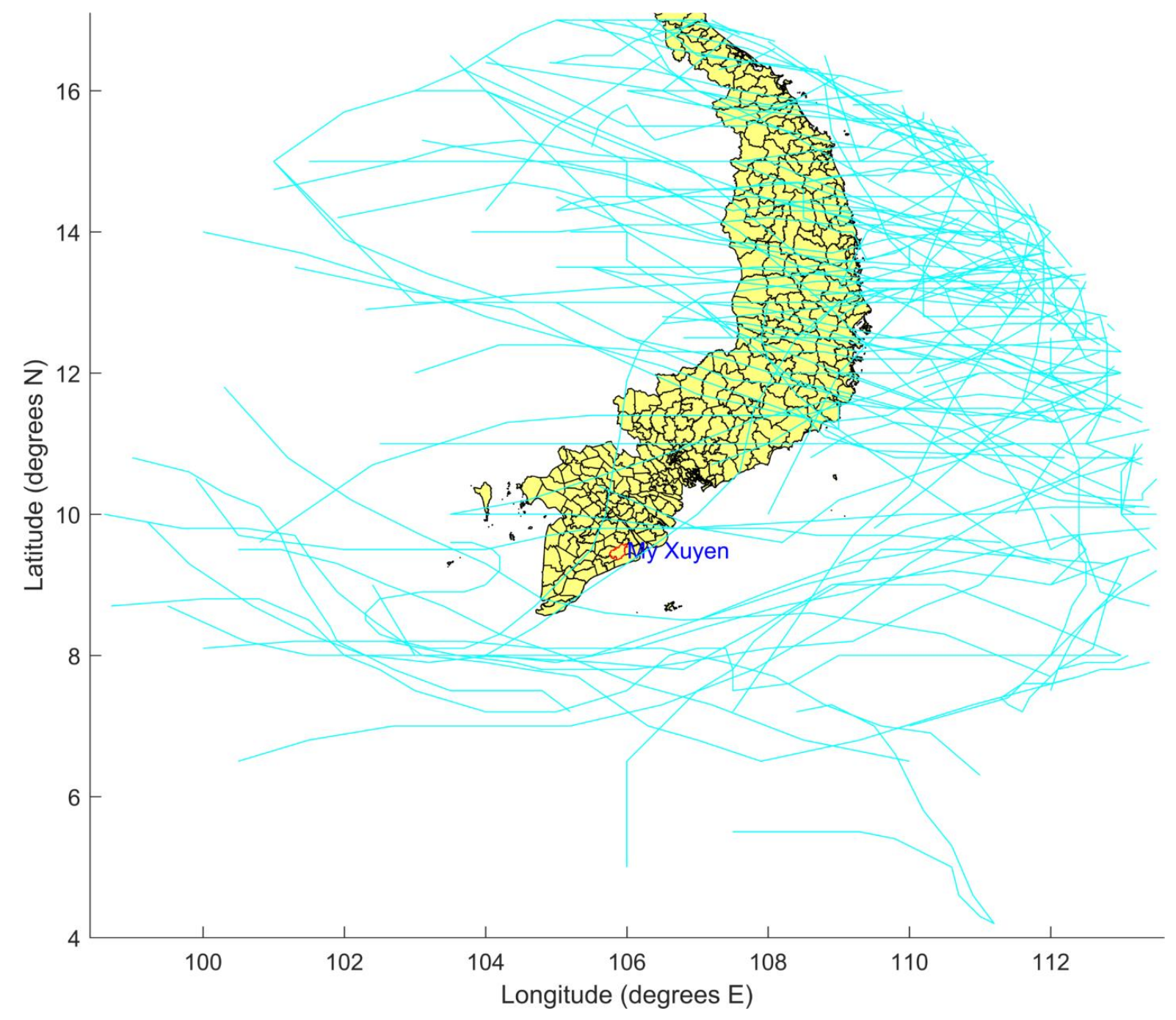

227 Figure 3. Tropical cyclone tracks (1951-2019) within the region in which they can affect My 228 Xuyen. 


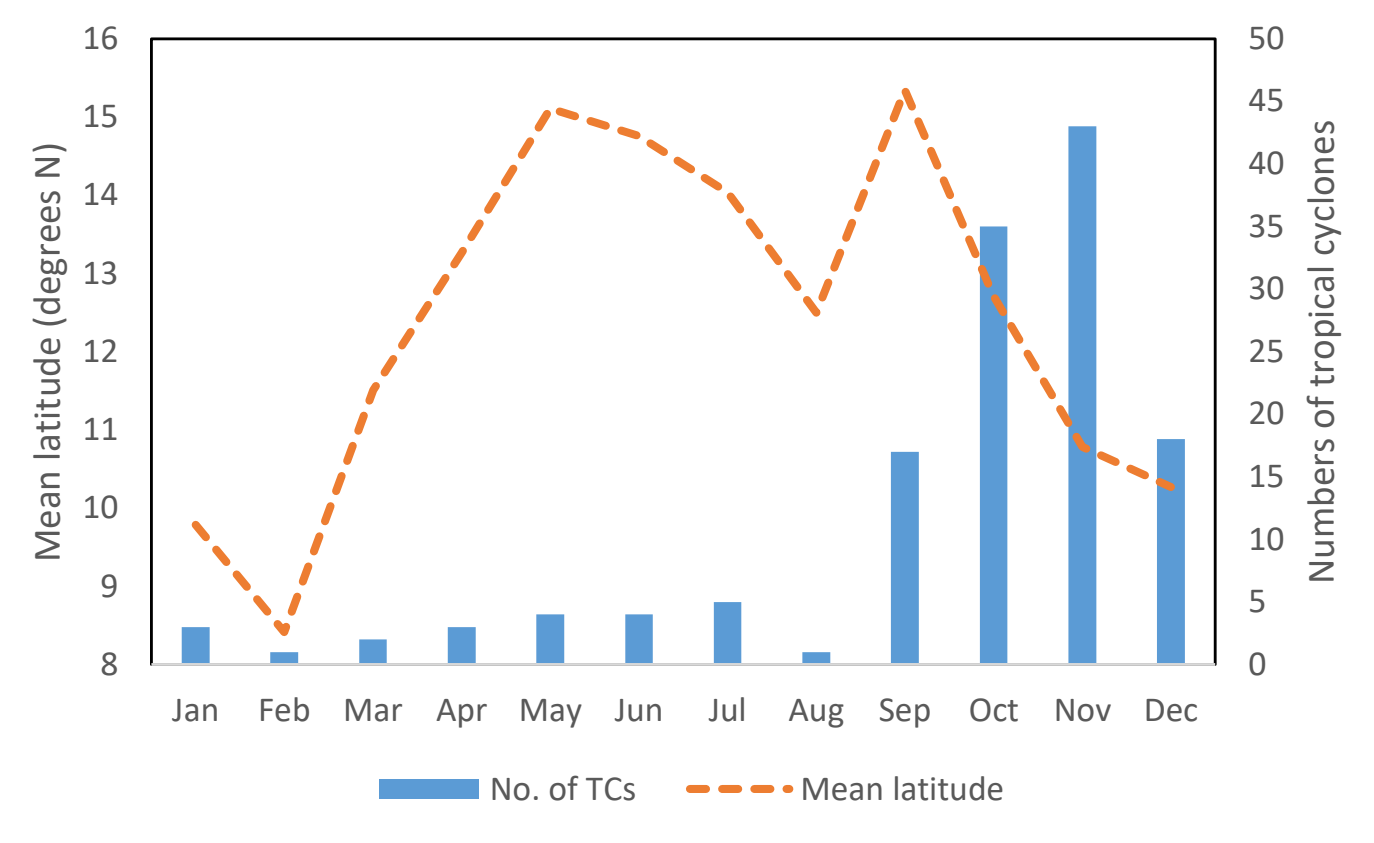

230 Figure 4. Monthly numbers and mean latitude of tropical cyclones from 1951 to 2019.

231 We calculated the monthly TCI of all tropical cyclones from 1951 to 2019 (Table 4) in order to 232 identify stress timing due to tropical cyclones. The results clearly show that November has the 233 highest TCI value, followed by October since these two months have the greatest occurrence of 234 tropical cyclones. Although September and December have similar numbers of tropical cyclones, 235 the TCI value of December is considerably higher than that of September. This happens because 236 tropical cyclones in December tends to get closer to My Xuyen. Consequently, October and

237 November are the most hazardous period, which are categorized as high and very high 238 respectively.

239 Table 4. Hazard indexes of tropical cyclones and salinity.

\begin{tabular}{|l|l|l|l|l|l|l|l|l|l|l|l|l|}
\hline Month & Jan & Feb & Mar & Apr & May & Jun & Jul & Aug & Sep & Oct & Nov & Dec \\
\hline
\end{tabular}




\begin{tabular}{|c|c|c|c|c|c|c|c|c|c|c|c|c|}
\hline $\begin{array}{l}\text { Average } \\
\text { TCI }\end{array}$ & 49 & 482 & 131 & 173 & 336 & 242 & 160 & 11 & 1285 & 8646 & 13065 & 4709 \\
\hline$H I_{\text {Tropical }}$ & & & & & & & & & & & & \\
\hline cyclones & 0.00 & 0.04 & 0.01 & 0.01 & 0.03 & 0.02 & 0.01 & 0.00 & 0.10 & 0.66 & 1.00 & 0.36 \\
\hline$H I_{\text {Salinity }}$ & 0.60 & 0.76 & 0.96 & 1.00 & 1.00 & 0.98 & 0.68 & 0.34 & 0.43 & 0.40 & 0.46 & 0.48 \\
\hline$H I$ & 0.59 & 0.77 & 0.95 & 1.00 & 1.00 & 0.98 & 0.68 & 0.34 & 0.44 & 0.52 & 0.63 & 0.54 \\
\hline \multicolumn{2}{|c|}{ Very low } & \multicolumn{2}{|r|}{ Low } & & \multicolumn{2}{|c|}{ Moderate } & \multicolumn{2}{|c|}{ High } & & \multicolumn{3}{|c|}{ Very high } \\
\hline
\end{tabular}

240 Saltwater intrudes into My Xuyen district through the My Thanh River (

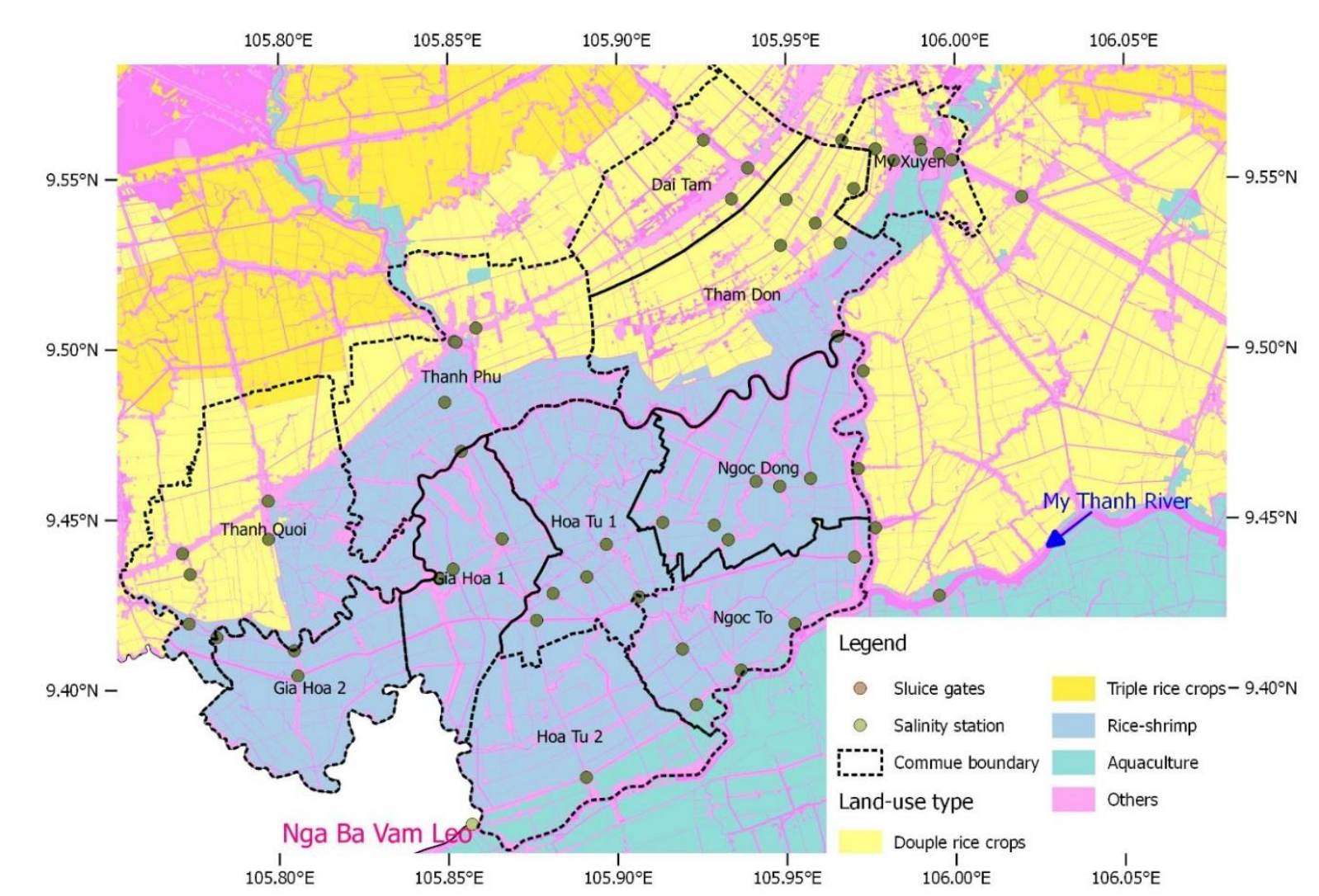

242 The My Thanh River is strongly dominated by the coastal processes and marginally controlled 
243 by the fluvial process. Thus surface water resources become saline due to effects of the coastal

244 processes. Figure 5 presents variations of daily maximum salinity at Nga Ba Vam Leo station

245 from 2016 to 2019. It obviously depicts that saline intrusion are varied seasonally. Specifically,

246 salinity reaches the highest level in April or May when river flows are low in the dry season; in

247 contrast, salinity becomes lowest in September coinciding with high river flows in the rainy

248 season in the Mekong Delta. However, salinity at Nga Ba Vam Leo is generally higher than the

249 S1 level in which rice yield can be reduced by $25 \%$. Therefore, surface water resources at Nga

$250 \mathrm{Ba}$ Vam Leo need to be noticed to use for rice irrigation. This results in high values of salinity

251 hazard index over the year. The salinity hazard indexes are usually categorized as moderate, high

252 and very high (Table 4).

253 Based on the rates of saline intrusion and tropical cyclones influencing agricultural cropping 254 systems in My Xuyen, saline intrusion is the main phenomenon damaging rice crops while

255 tropical cyclones has much less impact. The ratio of saline intrusion to tropical cyclones impacts

256 is approximately $85: 15$. This ratio is relatively reasonable because probability of tropical

257 cyclones is low while saline intrusion frequently happens in My Xuyen. The multiple hazard

258 index (illustrated in Table 4) indicates that May-June is the most hazardous period for rice

259 production. This calculation agrees with the cropping calendar of the double rice cropping

260 system in My Xuyen This period is free in the cropping calendar (Nguyen et al. 2019) due to

261 very high hazard index. The lowest hazard appears in August, followed by a moderate hazard

262 period. Thus rice is cultivated during this period even in the rice-shrimp cropping system. 


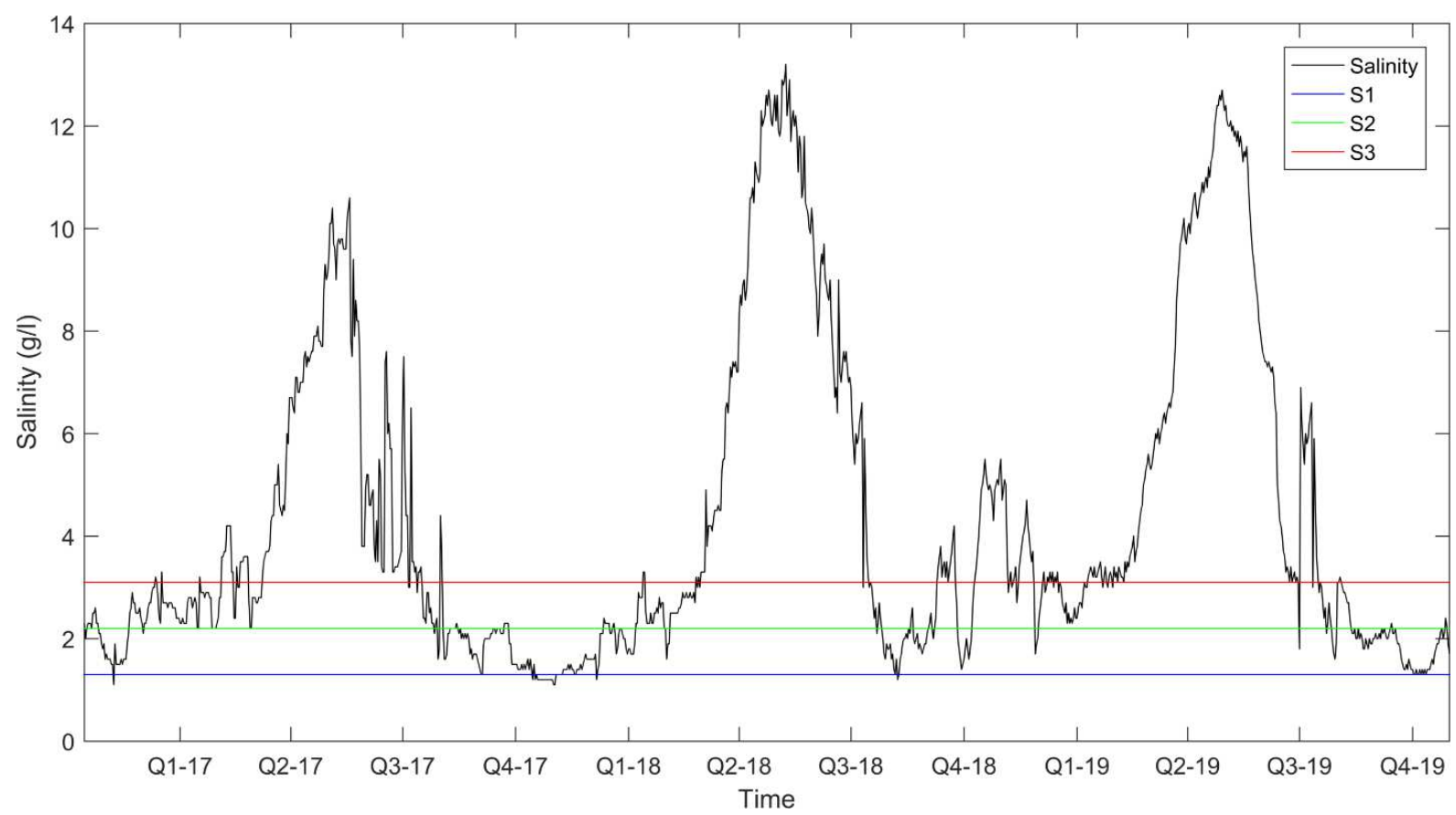

264 Figure 5. Daily maximum salinity at Nga Ba Vam Leo. S1, S2 and S3 are critical levels that 265 reduce rice yields of $25 \%, 50 \%$ and $75 \%$ respectively.

\subsection{Vulnerability}

267 Table 5 shows temporal variations of vulnerability index of a rice crop which indicates potential

268 effects of tropical cyclones and salinity, damaging at different growth phases. We found that rice

269 crops response to tropical cyclones and salinity differently. Rice is most vulnerable to tropical

270 cyclones at the heading stage and to salinity at the panicle initiation phase. Noticeably, the first

271 half of rice crop is highly vulnerable to salinity while the second half is considerably damaged

272 due to tropical cyclones. The combined vulnerability index is averaged and normalized. It shows

273 that the panicle initiation stage has the highest value of the combined vulnerability index,

274 followed by the heading stage with an index of 0.66 .

275 Table 5. Vulnerability index of a rice crop. 


\begin{tabular}{|l|l|l|l|l|l|l|}
\hline Growth phase & Seedling & Tillering & Panicle & Heading & Ripening & Harvesting \\
initiation & & & & & & \\
\hline Days after sowing & 1 & 20 & 50 & 70 & 100 & 105 \\
\hline $\begin{array}{l}\text { Vulnerability to tropical } \\
\text { cyclones }\end{array}$ & 0.00 & 0.33 & 0.87 & 1.00 & 0.77 & 0.67 \\
\hline $\begin{array}{l}\text { Vulnerability to salinity } \\
0.64\end{array}$ & 0.64 & 1.00 & 0.23 & 0.08 & 0.08 \\
\hline $\begin{array}{l}\text { Combined vulnerability } \\
\text { index }\end{array}$ & 0.34 & 0.52 & 1.00 & 0.66 & 0.45 & 0.4 \\
\hline
\end{tabular}

276 Rice cultivated in My Xuyen are usually short-duration varieties which mature in a range of 105-

277120 days. This is coincided with surveyed data in My Xuyen district recently (Nguyen et al.

278 2019). Table 6 presents cropping calendar or the double rice and rice-shrimp cropping system in

279 My Xuyen. The double rice cropping system includes Summer-Autumn (from June to

280 September) and Winter-Spring (October to January) crops. The rice crop in the rice-shrimp

281 cropping system is cultivated from September to December. The cropping calendar of each

282 system was used for computing vulnerability index which is depicted in Table 6. My Xuyen

283 district has highly potential damage to rice in October and November because it has the largest

284 area of rice production at the reproductive phase in the both cropping systems. In contrast, there

285 are no damage of rice crops from February to May because of no rice grown during this period.

286 This period was obviously coincided with the highest salinity in My Xuyen. It can be explained

287 that the local community and farmers may have a measure to adapt to saline intrusion by

288 adjusting the cropping calendar. Consequently, saline intrusion is the most hazardous events in 
this area.

290 Table 6. Cropping calendar of rice-based farming systems in My Xuyen (after Nguyen et al.,

291 2019) and rice vulnerability index.

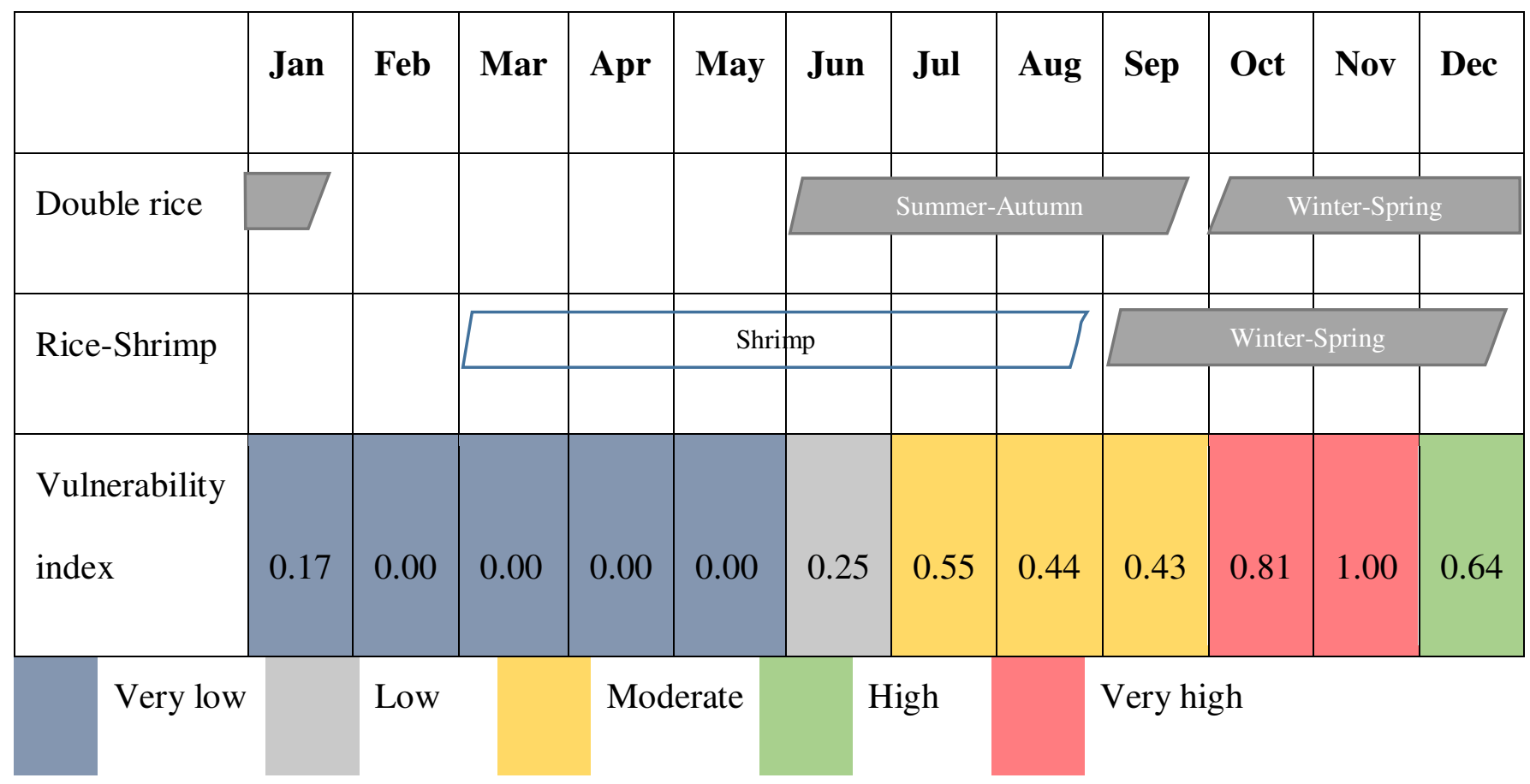

\subsection{Multi-hazard risk}

293 Based on the hazard and vulnerability identification, monthly risk indexes indicate possibility of

294 rice damage or loss due to effects of tropical cyclones and saline intrusion, are presented in Table

295 7. October and November belong to the high category while February-May have no risk. The

296 rice crop is at no risk from February to May and this is resulted from no rice crop cultivated

297 during this period. The high risk of rice production in October and November is occurred

298 because of very high vulnerability and high hazard. Results of the temporal analysis have a

299 reasonable agreement with Wassmann et al. (2019) outputs of risk analysis for the coastal VMD

300 in general.

301 Table 7. Monthly risk of rice to multiple hazards. 


\begin{tabular}{|c|c|c|c|c|c|c|c|c|c|c|c|c|}
\hline Month & Jan & Feb & Mar & Apr & May & Jun & Jul & Aug & Sep & Oct & Nov & Dec \\
\hline Risk & 0.10 & 0.00 & 0.00 & 0.00 & 0.00 & 0.24 & 0.37 & 0.15 & 0.19 & 0.42 & 0.63 & 0.34 \\
\hline \multicolumn{2}{|c|}{ Very low } & \multicolumn{2}{|c|}{ Low } & & \multicolumn{2}{|c|}{ Moderate } & \multicolumn{2}{|c|}{ High } & & \multicolumn{3}{|c|}{ Very high } \\
\hline
\end{tabular}

302 The nature of risks is considerably useful for assessing potential impacts of tropical cyclones and

303 saltwater intrusion on rice production. It is noticed that the damages of agricultural crops vary

304 with timing of the hazards and crop growth stages. Therefore, to reduce the risks, it needs to

305 reduce hazards or/and vulnerability. First, the hazards can be reduced by improving early

306 warning system. The hazardous phenomenon are tropical cyclones and salinity which are

307 possibly predicted by their dominated factors. For example, tropical cyclones are predicted by

308 several predominant factors (Safaripour et al. 2012; Camargo et al. 2019). The salinity is usually

309 projected by the El Niño-Southern Oscillation indexes (Apel et al. 2020) or water discharge of

310 the Mekong River (Dat et al. 2011). In addition, a structure such as sluice gates is a common

311 measure to prevent saline intrusion in coastal areas. Second, there are some solutions to reduce

312 vulnerability of rice-based cropping systems, including using salt-tolerant varieties, adjusting

313 cropping calendar and changing to other agricultural crops (Renaud et al. 2015; Thảo et al.

314 2017). The results of risk assessment can help the local community become more resilient in rice

315 cultivation to the natural hazardous events.

\section{4. Conclusions}

317 We assessed multiple natural hazards of tropical cyclones and saline intrusion. These hazardous

318 events are the major factors, causing significant damages on rice crops in My Xuyen district. To

319 assess risk of the multiple natural hazards, we used a framework of risk on rice crops in a coastal 
320 area (My Xuyen, Soc Trang). The study primarily focused on evaluation of potential impacts of

321 the mentioned hazards on rice crops. A temporal analysis was embedded in risk assessment

322 because rice crops vary seasonally.

323 The study have shown that rice crop may face extreme salinity from March to June while it deals 324 with tropical cyclones in October and November. These hazards have various effects on rice 325 crops. Rice crops are considerably susceptible to salinity during the first half of the growing 326 period and to tropical cyclones during the other half. In general, therefore, the results show that 327 rice crops are sharply susceptible in the reproduction phase to the combination of salinity and 328 tropical cyclones. For rice cultivation in My Xuyen, it is considerably vulnerable to these hazards 329 in October and November based on the cropping calendar. We found that the rice crops are at 330 high risk in October and November. Our findings are that saline intrusion reaches the highest 331 level in April and May, but the rice crop was at no risk because of no rice crop cultivated during 332 this period.

333 The multiple hazard assessment provides essential information for the case study in order to 334 create an awareness for natural disaster mitigation. In addition, the integrated result of multiple

335 hazards is much more simply than these of each hazard in providing information to planners and 336 decision-makers because many numbers and scales can be confusing and cumbersome to them. If 337 the results of multi-hazards and risk assessment are used efficiently, it can reduce damage or loss 338 of rice crops/yield. However, this needs an effort of users who convey the information to the 339 natural disaster mitigation procedure. An implication of these findings is to assist decision340 makers, planners and managers in mitigation and adaptation strategies. 


\section{List of abbreviations}

342 VMD: the Vietnamese Mekong Delta; TCI: Tropical Cyclone Potential Index; EC: Electrical

343 conductivity; SPI: Salinity Potential Index.

\section{Availability of data and materials}

345 The datasets generated and/or analysed during the current study are available from the

346 corresponding author on reasonable request.

\section{Competing interests}

348 The authors declare that they have no competing interests.

\section{Funding}

350 This study was funded in part by the Can Tho University Improvement Project VN14-P6, 351 supported by a Japanese ODA loan.

\section{Authors' contributions}

353 VQT and NHT were responsible for conceptualizing this study and formal analysis. VTPL was

354 responsible for data curation. VQT wrote the initial draft and all authors contributed to the 355 manuscript by providing comments and suggestions.

\section{Acknowledgements}

357 The authors would like to thank staff at Department of Agriculture and Rural Development of 358 My Xuyen district for their support.

\section{References}

360 Ali NS, Mo K, Kim M (2012) A case study on the relationship between conductivity and 361 dissolved solids to evaluate the potential for reuse of reclaimed industrial wastewater. 
KSCE J Civ Eng 16:708-713. https://doi.org/10.1007/s12205-012-1581-X

363

364

Apel H, Khiem M, Hong Quan N, Quang Toan T (2020) Brief communication: Seasonal prediction of salinity intrusion in the Mekong Delta. Nat Hazards Earth Syst Sci 20:16091616. https://doi.org/10.5194/nhess-20-1609-2020

Asch F, Wopereis MCS (2001) Responses of field-grown irrigated rice cultivars to varying levels of floodwater salinity in a semi-arid environment. F Crop Res 70:127-137. https://doi.org/10.1016/S0378-4290(01)00128-9

Ayers RS, Westcot DW (1985) Water quality for agriculture. FAO irrigation and drainage paper 29 Rev 1, Rome, Italia

Balica S, Dinh Q, Popescu I, et al (2014) Flood impact in the Mekong Delta, Vietnam. J Maps 10:257-268. https://doi.org/10.1080/17445647.2013.859636

Balica SF, Wright NG, Meulen F (2012) A flood vulnerability index for coastal cities and its use in assessing climate change impacts

Bates PD, Pappenberger F, Romanowicz RJ (2014) Uncertainty in flood inundation modelling. In: Applied Uncertainty Analysis for Flood Risk Management. pp 232-269

Bauder TA, Waskom RM, Sutherland PL, Davis JG (2011) Irrigation water quality criteria. Colorado State University Extension Publication. Crop series: Irrigation

Bé NV, Trí VPĐ, Vũ PT, Vũ PH (2017) Challenges in agriculture in My Xuyen district, Soc Trang province in the context of saline intrusion. Can Tho Univ J Sci 2:187-196. https://doi.org/10.22144/ctu.jsi.2017.067

Buan RD, Maglinao AR, Evangelista PP, Pajuelas BG (1996) Vulnerability of rice and corn to climate change in the Philippines. Water Air Soil Pollut 92:41-51. https://doi.org/10.1007/978-94-017-1053-4_4

Camargo SJ, Camp J, Elsberry RL, et al (2019) Tropical cyclone prediction on subseasonal timescales. Trop Cyclone Res Rev 8:150-165. https://doi.org/10.1016/j.tcrr.2019.10.004

Dat TQ, Likitdecharote K, Srisatit T, Trung NH (2011) Modeling the influence of river discharge and sea level rise on salinity intrusion in the Mekong Delta. In: The 1st Environment Asia International Conference on Environmental Supporting in Food and Energy Security: Crisis 
and Opportunity. Thai Society of Higher Education Institutes on Environment, pp 685-701

391 Esteban M, Takagi H, Thao ND (2014) Tropical Cyclone Damage to Coastal Defenses: Future

Grattan SR, Zeng L, Shannon MC, Roberts SR (2002) Rice is more sensitive to salinity than previously thought. Calif Agric 56:189-198

GSOVN (GENERAL STATISTICS OFFICE of VIET NAM) (2010) Statistical yearbook of Vietnam. Hanoi

Hakim MA, Juraimi AS, Begum M, et al (2010) Effect of salt stress on germination and early seedling growth of rice (Oryza sativa L.). African J Biotechnol 9:1911-1918

IPCC (2014) Summary for policy makers. In: Field CB, Barros VR, Dokken DJ, et al. (eds) Climate Change 2014: Impacts,Adaptation, and Vulnerability. Part A: Global and Sectoral Aspects. Contribution of Working Group II to the Fifth Assessment Report of the Intergovernmental Panel on Climate Change. Cambridge University Press, Cambridge, United Kingdom and New York, NY, USA, pp 1-32

IRRI (2015) IRRI Rice Production Manual: Steps to successful rice production. International Rice Research Institute, Los Baños (Philippines)

Kakar N, Jumaa SH, Redoña ED, et al (2019) Evaluating rice for salinity using pot-culture provides a systematic tolerance assessment at the seedling stage. Rice 12: https://doi.org/10.1186/s12284-019-0317-7

Kakonen M (2008) Mekong Delta at the crossroads: More control or adaptation? Ambio 37:205212

Kunitsugu M (2012) Tropical cyclone information provided by the RSMC Tokyo - Typhoon Center. Trop Cyclone Res Rev 1:51-59. https://doi.org/10.6057/2012TCRR01.06 
417 Lee T-C, Knutson TR, Kamahori H, Ying M (2012) Impacts of climate change on tropical 418 cyclones in the Western North Pacific Basin. Part I: Past observations. Trop Cyclone Res $419 \quad \operatorname{Rev} 1: 213-235$. https://doi.org/10.6057/2012TCRR02.08

420 Masutomi Y, Iizumi T, Takahashi K, Yokozawa M (2012) Estimation of the damage area due to 421 tropical cyclones using fragility curves for paddy rice in Japan. Environ Res Lett 7:. 422 https://doi.org/10.1088/1748-9326/7/1/014020

423 Mendelsohn R, Emanuel K, Chonabayashi S, Bakkensen L (2012) The impact of climate change 424 on global tropical cyclone damage. Nat Clim Chang 2:205-209.

425 https://doi.org/10.1038/nclimate1357

426

Merz B, Hall J, Disse M, Schumann A (2010) Fluvial flood risk management in a changing world. Nat Hazards Earth Syst Sci 10:509-527. https://doi.org/10.5194/nhess-10-509-2010

MRC (2010) State of the Basin Report 2010. Vientiane, Laos

Nguyen MT, Renaud FG, Sebesvari Z, Can Nguyen D (2019) Resilience of agricultural systems facing increased salinity intrusion in deltaic coastal areas of Vietnam. Ecol Soc 24:19. https://doi.org/10.5751/ES-11186-240419

Qadir M, Tubeileh A, Akhtar J, et al (2008) Productivity enhancement of salt-affected environments through crop diversification. L Degrad Dev 19:429-453. https://doi.org/10.1002/ldr

Rad HE, Aref F, Khaledian M, et al (2011) The effects of salinity at different growth stage on rice yield. In: ICID 21st International Congress on Irrigation and Drainage. Tehran, Iran, pp $155-165$

Renaud FG, Le TTH, Lindener C, et al (2015) Resilience and shifts in agro-ecosystems facing increasing sea-level rise and salinity intrusion in Ben Tre Province, Mekong Delta. Clim Change 133:69-84. https://doi.org/10.1007/s10584-014-1113-4

Safaripour M, Monavari M, Zare M, et al (2012) Flood Risk Assessment Using GIS ( Case Study: Golestan Province, Iran ). Polish J Environ Stud 21:1817-1824

Takagi H, Thao ND, Esteban M (2014) Tropical Cyclones and Storm Surges in Southern Vietnam. In: Coastal Disasters and Climate Change in Vietnam: Engineering and Planning 
Perspectives. Elsevier Inc., pp 3-16

446 Thảo NH, Trung NH, Trí LQ (2017) Establishing the model for supporting agricultural land use

447 allocation - A case study in My Xuyen district, Soc Trang province. Can Tho Univ J Sci

$448 \quad$ 2:166-177. https://doi.org/10.22144/ctu.jsi.2017.065

449 Tri VPD, Trung NH, Thanh VQ (2013) Vulnerability to flood in the Vietnamese Mekong Delta :

450 mapping and uncertainty assessment. J Environ Sci Eng B 2:229-237

451 Wang L, Zhou Y, Lei X, et al (2020) Predominant factors of disaster caused by tropical cyclones 452 in South China coast and implications for early warning systems. Sci Total Environ

$453 \quad$ 726:138556. https://doi.org/10.1016/j.scitotenv.2020.138556

454 Wassmann R, Phong ND, Tho TQ, et al (2019) High-resolution mapping of flood and salinity

455 risks for rice production in the Vietnamese Mekong Delta. F Crop Res 236:111-120.

456 https://doi.org/10.1016/j.fcr.2019.03.007

457 Xiao F, Yin Y, Luo Y, et al (2011) Tropical cyclone hazards analysis based on tropical cyclone

458 potential impact index. J Geogr Sci 21:791-800. https://doi.org/10.1007/s11442-011-0880-3

459 Zeng L, Lesch SM, Grieve CM (2003) Rice growth and yield respond to changes in water depth

460 and salinity stress. Agric Water Manag 59:67-75. https://doi.org/10.1016/S0378-

$461 \quad 3774(02) 00088-4$

462 Zeng L, Shannon MC (2000) Salinity effects on seedling growth and yield components of rice.

463 Crop Breeding, Genet Cytol 40:996-1003

464 Zeng L, Shannon MC, Lesch SM (2001) Timing of salinity stress affects rice growth and yield 465 components. Agric Water Manag 48:191-206

466 
Figures

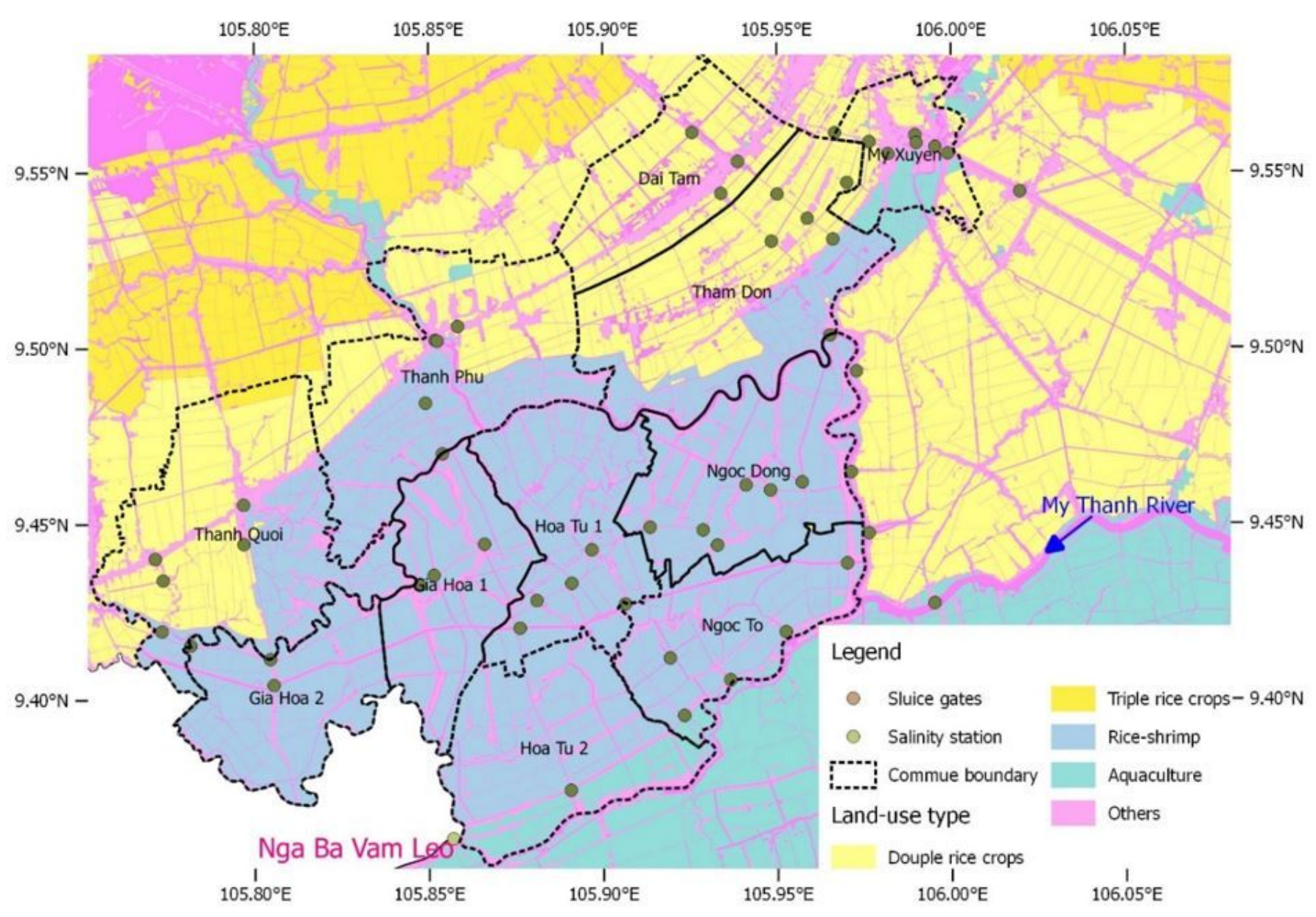

Figure 1

Land-use map in 2010 of My Xuyen district. 


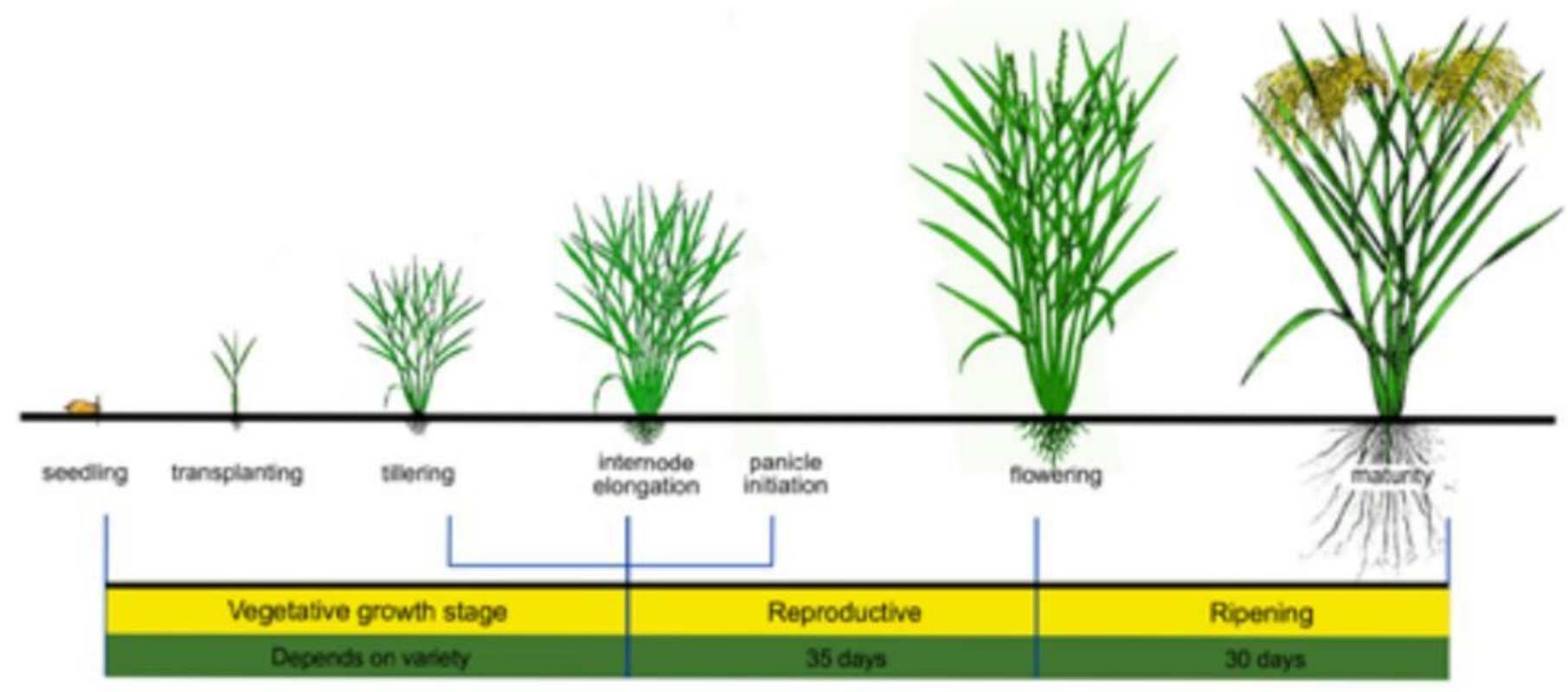

Figure 2

The growth stages of rice (IRRI 2015). 


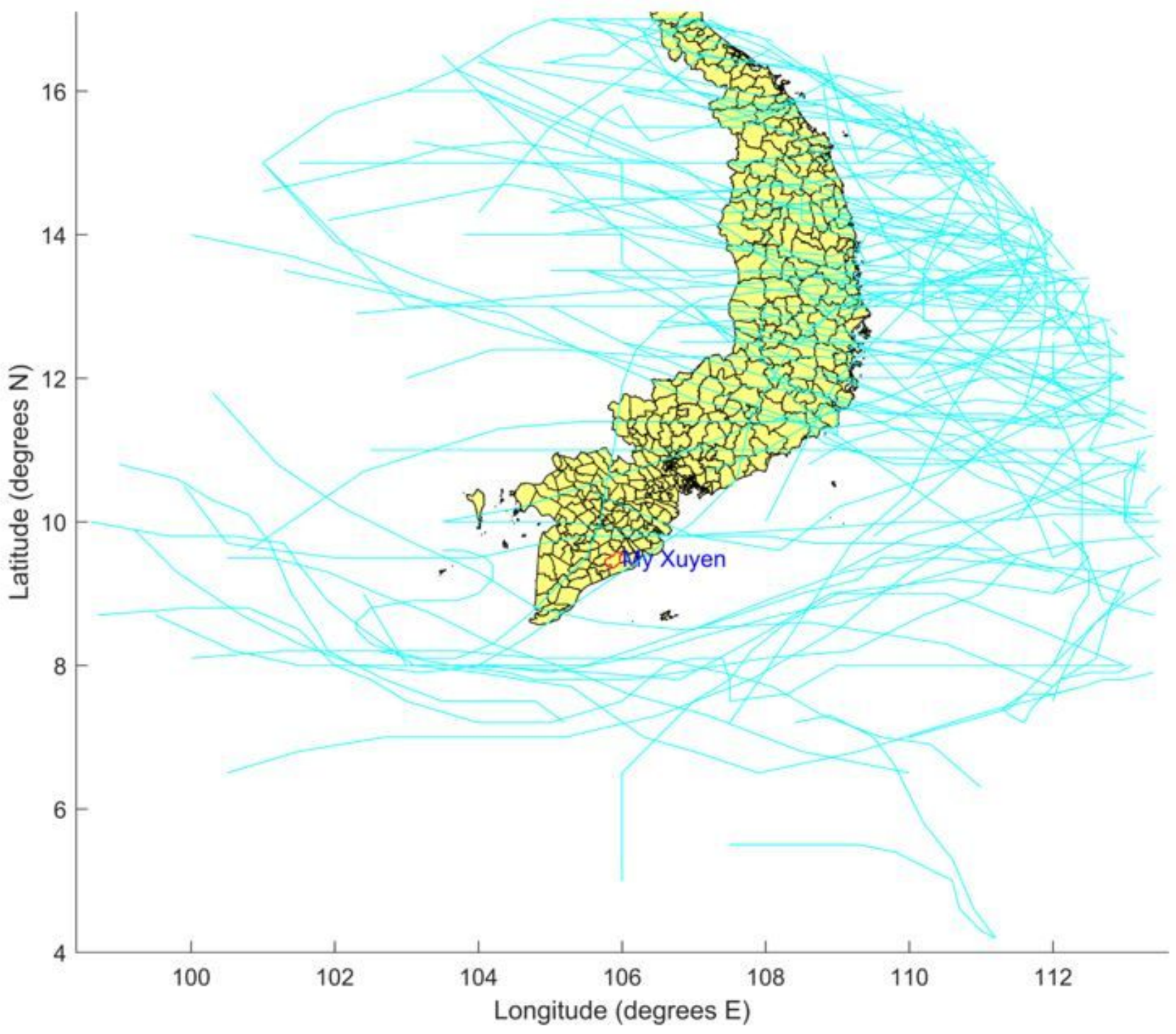

Figure 3

Tropical cyclone tracks (1951-2019) within the region in which they can affect My Xuyen. 


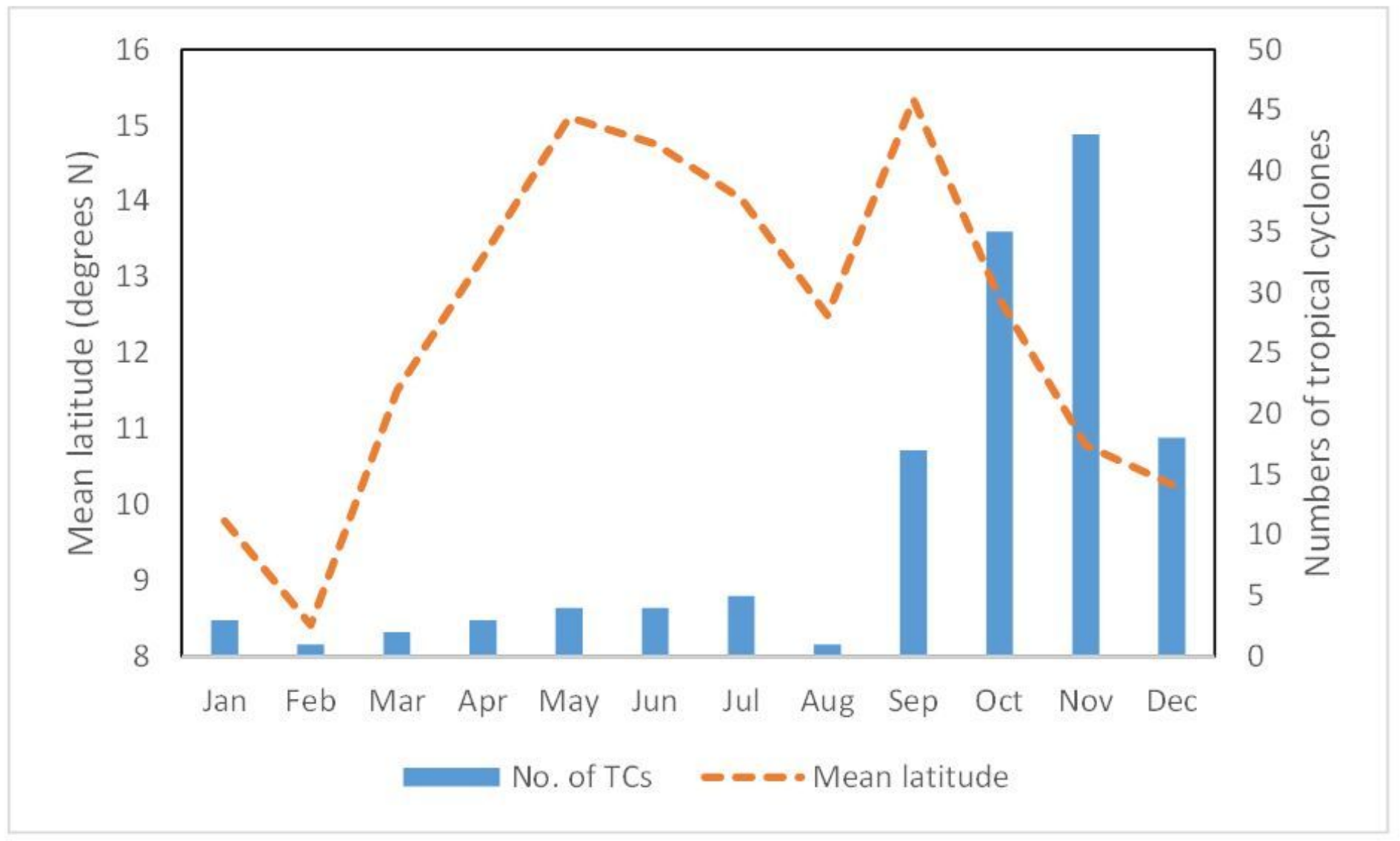

Figure 4

Monthly numbers and mean latitude of tropical cyclones from 1951 to 2019. 


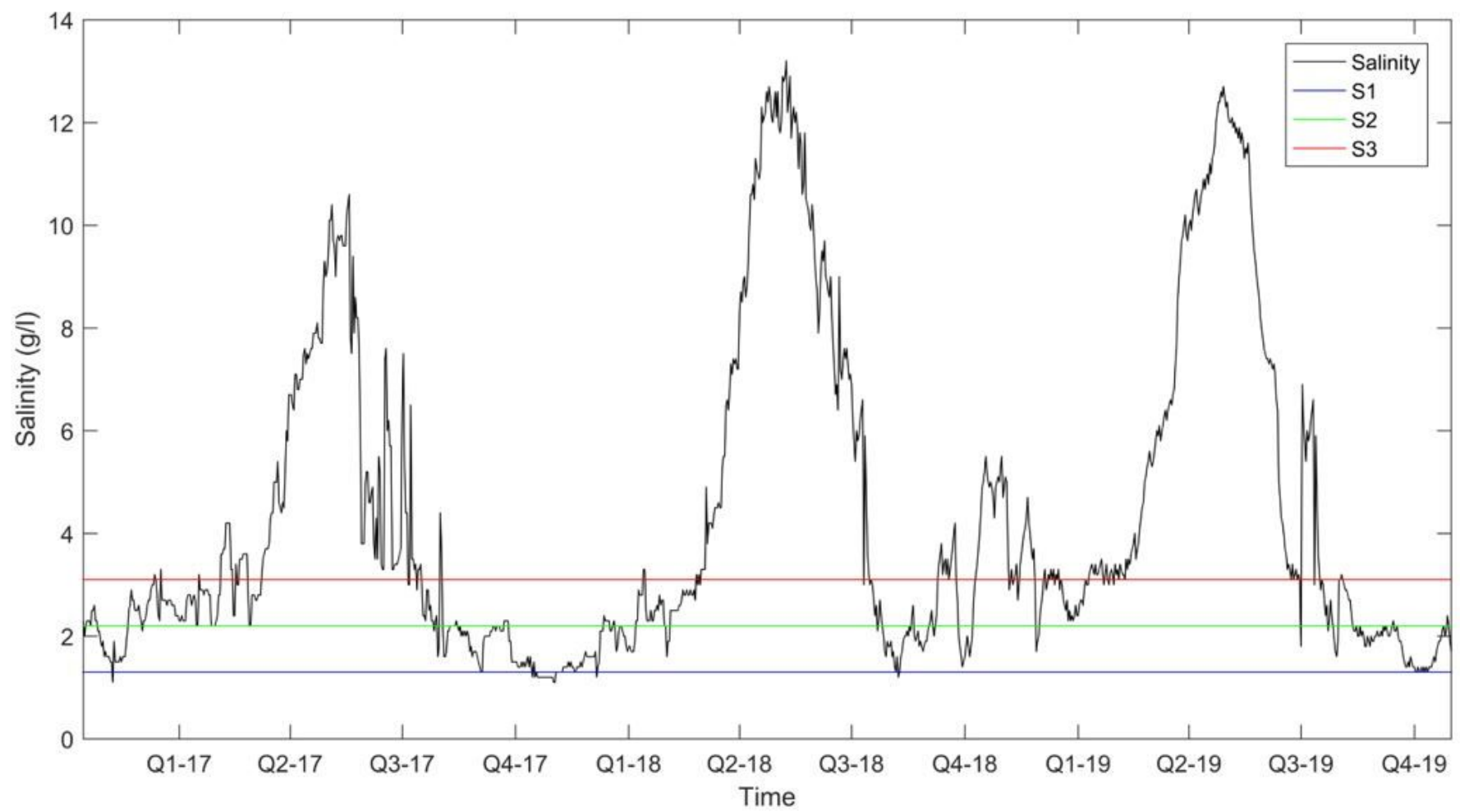

Figure 5

Daily maximum salinity at Nga Ba Vam Leo. S1, S2 and S3 are critical levels that reduce rice yields of $25 \%, 50 \%$ and $75 \%$ respectively. 